\title{
Tarık Artel ve \\ Türkçe Kimya Terminolojisi
}

\author{
IRFAN ELMACI ${ }^{*}$
}

\begin{abstract}
ÖZ
Türkçe kimya terminolojisi alanında yazılmış eserlerden biri Tarık Artel'in 1935 yılında basılmış Türkçe Kimya Nomenclaturu Nasıl Olmalıdır başlıklı kitabıdır. Kimya terminolojisi oluşturma çabalarının yoğun olarak devam ettiği 1930'lu yıllarda, bu kitabı ile konuyu etraflıca tartışan Artel bu sahada bir ilki gerçekleştirmiştir. Lakin görüşleri kabul görmeyen araştırmacı, Türkçe kimya terminolojisinin durumunu dikkate alarak bu konuya eğilmeyi gerekli görmüş ve bunun üzerine 1953'te "İlmî Termler Hakkında" başlıklı bir yazı kaleme almıştır. Bahsedilen kitabın ve yazının temel alındı̆̆ı bu makalede, bunlardan hareketle Artel'in terminoloji üzerine olan görüşleri ortaya konulmuştur. Elde edilen çıktılar ışığında, araştırmacının Türkçe kimya terminolojisinin gelişimine yaptığı katkılar ve Türk kimya bilimindeki konumu okuyucunun takdirine bırakılmıştır.
\end{abstract}

Anahtar sözcükler: Kimya, Türkçe, terminoloji, Tarık Artel, Türkçe Kimya Nomenclaturu Nasıl Olmalıdır

$\mathrm{T}$ ürkçe kimya terminolojisi konusunda birçok çalışma yapılmış, kurumsal ve kişisel eserler yayımlanmıştır. Bu çalışmalar 1930’larda yoğunlaşmış; Türk Dil Kurumu, Kültür Bakanlığı, Maarif Vekilliği'nin de aralarında bulunduğu kurum ve kuruluşlar bahsedilen konuyla ilgili rapor ve sözlükler hazırlamışlardır.

Bu kapsamda Türk Dil Kurumu'nca yapılan çalışmalardan biri, 5 İlk Kânun 1936'da Akil Muhtar Özden başkanlığında ve üyeleri Prof. Fritz Arndt, Prof. Hayrullah Diker, Prof. Necmeddin Rifat Yarar ile İbrahim Etem'den oluşan Kimya Terimleri Komisyonu'nun faaliyetleridir (Özden 1938: 1-2). Kültür

\footnotetext{
* Dr., Bilim, Sanayi ve Teknoloji Bakanlı̆ğ/ANKARA

E-posta: irfanelmaci@yahoo.com
} 
Bakanlığı'nın 1937'de basılmış İlk ve Orta Öğretim Kimya Terimleri, Elemanların Adları İle Bileşik Cisimlerin Genel Adlanma Yolları, İlk ve Orta Öğretim Kimya Terimleri kitaplarında; Türkçe-Osmanlıca, Osmanlıca-Türkçe, Fransızca-Türkçe sözlükçeler hazırlanmıştır. Bir diğer çalışma Maarif Vekilliği tamimidir; bu yolla okullarda okutulan ders kitapları öğretmenlere tetkik ettirilmiş, yerinde görülen tenkitler ışığında kitaplar yeniden basılmıştır (Bkz. Kimya Kitapları Düzeltme Kılavuzu). Neticede bu ve benzeri çalı̧̧malarla çok sayıda yeni terim Türkçe kimya terminolojisine kazandırılmıştır. Bunların yanısıra Türkçe kimya terminolojisine özgü yapıtlar da vardır. Bunlardan biri Tarık Artel'in Türkşe Kimya Nomenclaturu Nasıl Olmalıdır başlıklı kitabıdır. Artel, 1935'te basılmış bu çalışmasıyla ilgi uyandırmış, ilerleyen senelerde konuyla alakalı düşünce ve önerilerini farklı platformlarda paylaşmıştır.

Sözü edilen uğraşları ortaya koymayı amaçlayan bu makalede, öncelikle Artel'in özgeçmişine değinilmiş ve terminoloji alanındaki eserleri incelenmiştir. Ardından Türkşe Kimya Nomenclaturu Nasıl Olmalıdır başlıklı kitabı irdelenmiştir. Ayrıca Ağustos 1953 tarihinde Kimya ve Sanayi mecmuasında yayımlanmış olan "İlmî Termler Hakkında" başlıklı makalesi incelenerek Artel'in Türkçe kimya terminolojisindeki konumu saptanmaya çalı̧ıllmıştır.

\section{Tarık Artel Hakkında}

Artel, Arnavut menşeli Arslan Paşa ailesinin bir ferdi olarak 1908'de Selanik'te doğmuştur. Babası Talât Paşa kabinesinde Dâhiliye Müsteşarı olan ve II. Dünya Savaşı sırasında Kocaeli Mebusu olarak Büyük Millet Meclisi üyeliğine seçilen Suphi Bey'dir. Orta tahsilini Kadıköy'deki Saint-Joseph Lisesi'nde, yüksek tahsilini Lyon Üniversitesi'nde yaparak 1932'de Kimya Yüksek Mühendisi olmuştur. Önce Ankara'da sanayi müfettişliği yapan Artel, 1933’te

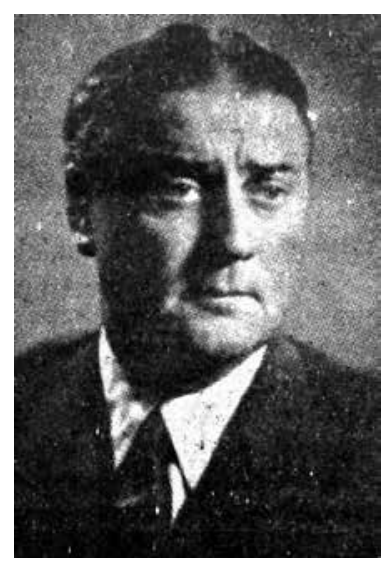

$(1908-1966)$
İstanbul Üniversitesi Fen Fakültesi Umumî Kimya Kürsüsü'nde göreve başlamıştır (Terem 1967: 75). 1933 Üniversite Reformu sonrasında Fen Fakültesi'ndeki öğretim kadrosu yeniden düzenlenmiş, Umumî Kimya Kürsüsü’ne müdür olarak Alman Prof. Fritz Arndt atanmıştır. Artel bu kürsüden 1936'da ayrılmı̧, Fizikokimya Enstitüsü'ne geçmiştir (Ertem 1982: 66-67). Sonrasında İstanbul Üniversitesi'nden de ayrılmış, İstanbul Güzel Sanatlar Akademisi'ne geçerek burada eğitimci olarak görev almıştır. Türk Kimya Cemiyeti’nde genel sekreterlik ve başkanlık yapmış, Fransız-Türk Mühendisleri Dostluk Cemiyeti İstanbul Kolu 
Başkanlığı'nı yürütmüştür (Terem 1967: 76). Artel'in alanla ilgili başlica eserleri şunlardır (Terem 1967: 76):

-Türkse Kimya Nomenclaturu Nasıl Olmalidir (1935)

-Kimya Tedrisatında Laboratuvarların Rolü (1938)

-Kimya (A. Tian ve J. Roche) (1940)

-1839'dan 1939'a Kadar Türkiye'de Kimya Tedrisatı (1940)

-Evolution de l'Enseignement des Sciences physiques en Turquie (1940)

- Étude de l'effet corrosif de l'eau de la mer de Marmara sur quelques métaux et alliages (1942)

-Radioactivité (Madame Curie) (1950)

-Considération scientifiques et didactiques sur les matériaux de constructions (1951)

-Yapı Malzemesi Dersleri (1961)

Farklı konularda yazan Artel, edebiyata da ilgi göstermiş, ancak kimyayla bağını hiç koparmamıştır. Kimya alanında Fransızcadan yaptığ ${ }_{1}$ çeviriler dikkat çekicidir; bu durum yüksek tahsilini Lyon Üniversitesi'nde yapmış olmasına bağlanabilir. Çevirilerinde aslına sadık kalma düşüncesini benimseyen Artel, ilmî kelimelerin orijinalini mümkün olduğunca bozmamaya gayret etmiştir. Türkşe Kimya Nomenclaturu Nasıl Olmalıdır'ı da bu düşünceyle yazmıştır.

\section{Türkçe Kimya Nomenclaturu Nasıl Olmalıdır}

1930'larda İstanbul Üniversitesi Kimya Enstitüsü'nde kimya lisanını sistematik hâle getirme çabaları sürmektedir. Artel burada Fen Fakültesi Umumî Kimya doçentidir ve bu çalışmaların içindedir. Uğraşılarını ve bu bahisteki birikimini bir araya getirmek maksadıyla Türkçe Kimya Nomenclaturu Nasıl Olmalıdır' 1 kaleme almış, kimya terminolojisini etraflıca tartışmıştır. Kitap şu üç bölümden oluşmaktadır: "Başlangıç", "Umumî Mülahazalar", "Nomenclatur (İsim Verme Sistemi)".

"Başlangıç" kısmında kitabını yazma nedenini gerekçelendiren Artel, "Umumî Mülahazalar" kısmında konuyu geniş biçimde tartışarak düşüncelerini açıklamı̧ ve önerilerde bulunmuştur. "Başlangıç”ta ilim ve fennin ilerlemesinde lisanın rolüne temas ederek bahsi kimya lisanı özeline getirmiştir. İstanbul Üniversitesi Kimya Enstitüsü'nde bir dereceye kadar sistematik hâle geldiğini belirttiği kimya lisanını, enstitü tekelinden ç1karmak için bu kitabı bastırdığını ifade etmiştir. Daha sonra "Nomenclatur" kısmında, İstanbul Üniversitesi Kimya Enstitüsü’nde kısmen kullanıldığını söylediği isim verme sisteminin ana hatlarını açmıştır. Kitabın

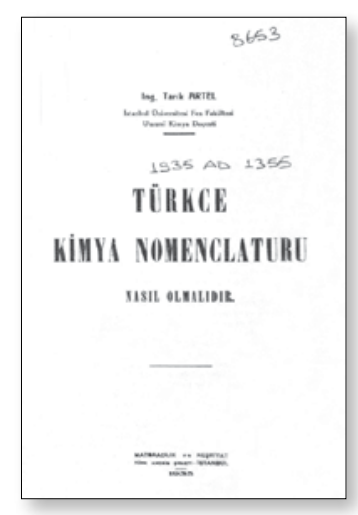


sonundaki "İlave"de ise okuyuculara tavsiyelerde bulunmuştur. Artel, isim verme sistemini enstitüdeki diğer meslektaşları ile birlikte geliştirdiklerini belirtmiştir. Ayrıca kitabın şahsi fikirlerini de ihtiva ettiğini, kitabın bazı kısımlarının teklif, deneme ve düşüncelerden başka bir şey olmadığını vurgulamı̧̧ıิır.

"Umumî Mülahazalar" kısmında, isim verme mevzuu etraflıca tartışılmıştır. Artel, Şark’ın bilim ve teknolojide eski ehemmiyetini yitirdiğini düşündüğünden, konuya Arap harflerinin bırakılarak Batı'ya dönülmesi gerektiği noktasından girmiştir. Zira ona göre, ilmî ilerlemeler Batı'da yaşandığından, Türkiye Batı'ya yönelme mecburiyetindedir. Batı'nın ilim, teknik ve her türlü kültür vasıtalarına kapılar açıldığında, Türkiye yeni kelime ve tabirlerle tanışacak, bunların Türkçeye kazandırılması gündeme gelecektir. Artel’e göre burada takip edilecek yol şudur: Şark kültüründen alınmış ama Türkçeleşmemiş, Arapça ve Acemce kelime ile tabirleri Türkçeden çıkartmak; yerlerine Batı'da kullanılan, uluslararası mahiyet kazanmış, üzerlerinde yıllarca çalışılarak işlenmiş, kolay anlaşılır ve Türkçeye uygun tabirleri almak. Yapılması gereken, her kavrama bir karşılık bulunması, yani Türkçeye birçok yeni sözcük kazandırılmasıdır. Fakat burada bir sorun vardır ki, fen lisanında gereksinim duyulan bu kelimeler nasıl bulunup Türkçeye kazandırılacaktır?

Artel bunun için evvela ilmî kelime köklerinin araştırılması gerektiği fikrindedir. Öyle anlaşılıyor ki bu neticeye Batı'nın ileri gelen lisanlarını tetkik ederek varmıştır. Zira anlattığına göre Fransızca, İngilizce, Almanca gibi lisanlardaki ilmî kelimelerde kökler muhafaza edilmiştir ve lisana uygun olarak bunlara birer ek ilavesi yapılmıştır. Sonuçta, köklere riayet edildiğinden ötürü bahsedilen bu lisanlarda ilmî kelimeler benzerdir. Artel'e göre İtalyancada kökler korunmamı̧ ve bu dil Fransızca, İngilizce ve Almancaya kıyasla etkisiz kalmıştır. Buna göre Türkiye, Avrupa’nın ileri gelen lisanlarını örnek mi almalıdır? Artel bu dillerin hiçbirinin Türkçeye büsbütün uymadığı, en doğru yöntemin Avrupa'nın bu ileri gelen lisanlarında yapıldığı gibi, sözcüklerin Latince ve Yunanca köklerinin araştırılarak Türkçe terimler üretilmesinden geçtiği fikrindedir. Zira köklerin değişime uğraması, mana açısından tehlikeli olmakla birlikte telaffuzda da yanılgıya sebep olacaktır. Kökleri alırken açı̆̆a ç1kan mesele ise Türk alfabesinde bulunmayan harflerdir. Mesela "oxygen" sözcüğünde $\mathrm{x}$ harfi vardır ve bu sözcük Türkçe kimya terminolojisine kabul edilirse sorun olacaktır. Artel bu sorunu aşmak için x, q ve w harflerinin Türk alfabesine alınmasını önermektedir. Alfabe hususunda sorun yaratan bir diğer nokta $\mathrm{k}$ ve $\mathrm{c}$ harflerinin durumudur. Zira diğer lisanlardaki yedi harfe karşl1ık Türkçede bir tek k harfi vardır ve bu etimoloji, okunuş ve anlaşı1ırlık açısından sakınca teşkil etmektedir. Bu nedenle, Latinceden Türkçe kimya lügatine alınacak sözcüklerdeki c harfi muhafaza edilmelidir. Örneğin 
"karbon" yerine "carbon" yazılmalıdır. Bunların telaffuzu ise ayrı bir meseledir. Artel fen lisanındaki bazı kavram, cisim, cihaz veya cihaz kısımlarına tekabül eden özel önemi haiz kelimelerin olduğu gibi alınması görüşündedir. Bunlar Türkçeye çevrilse bile yanına ana dildeki hallerinin konulması icap eder. Fransızcaları "gaz á l'eau" ve "gaz á l'air", Türkçeleri "su gazı" ve "havalı gaz" olan tabirler bunlardandır. Sonuçta, Artel’e göre Doğu kültürlerinden Batı kültürlerine geçerken Türkçeleşmemiş Arapça ve Acemce ilmî kelime ile tabirler Türkçeden atılmalı; yerlerine Batı'nın yerleşmiş, anlaşılması kolay tabirleri alınmalıdır. Bunu yaparken de kelimelerin kökü muhafaza edilmelidir. Bundan kasıt, diğer milletlerin telaffuzunu taklit değil, yabancı dillerden tercüme ve mütalaayı kolaylaştırmak, makul ve sağlam bir dil vücuda getirmektir. Böylece, Türkçe gramere ilave edilecek kaideleri ezberleme zahmetinden de kurtulmuş olunacaktır.

“Nomenclatur” kitabın en geniş kısmıdır. Artel burada, İstanbul Üniversitesi Kimya Enstitüsü’nde kısmen kullanıldığını ifade ettiği isim verme sistemini örneklerle anlatmıştır. "Umumî Mülahazalar" kısmındaki teklif ve düşüncelerine yer verdiği bu kısımda, sözcüklerin esasını bozmadan mümkün olduğu kadar Türkçeye uygun hale getirme düşüncesi esas alınmaktadır. Yazar bu bölümde, isim ve tabirleri "İnorganik Kimya", "Organik Kimya", "Cihaz ve Alet İsimleri” olmak üzere üçe ayırarak tetkik etmiş ve isimlendirmiştir. Öz Türkçesinin bulunamayacağını, içerisinde bir harf bile oynatılamayacağını düşündüğü örneklere ise kitabında özellikle yer vermiştir.

"İnorganik Kimya” bölümü; “elementler”, "birleşik cisimler” olmak üzere iki alt başlıktan meydana gelmiştir. Artel, "Elementler" başlığı altında periyodik tablodaki doksan iki elementi, keşfeden bilim adamlarınca verilen isimler, keşfedildikleri ülkeler ve ekseriyetle Fransızca, İngilizce, Almanca karşılıklarını göz önünde bulundurarak bir cetvelde toplamıştır. Burada element isimlerinin orijinal hallerini ekseriyetle korumuştur. Sadece Öz Türkçesi olan elementlerin Türkçesini cetvele koyarken, Öz Türkçe olanların Latincelerine de hatırlatmak üzere, cetvelde yer vermiştir. Öyle anlaş1lyyor ki, eğer tüm elementlerin Öz Türkçesi mevcut olsaydi, Artel periyodik tabloyu tam olarak Türkçeleştirmiş olacaktı. Fakat böyle bir durum mümkün olmadığından, Artel'in periyodik tablosu elementlerin farklı lisanlardaki isimlerini içeren karma bir görüntü sergilemiştir.

Artel, "birleşik cisimleri" ise "metal oxydleri", "esaslar", "nonmetal oxydleri veya anhydridler", "acidler", "tuzlar" alt başlıklarına ayırarak tetkik edip isimlendirmiştir. Örneğin, metallerin oksijenle bir araya gelerek oluşturdukları 
bileşikler için ismin sonuna "oxydi" ilavesinin getirilmesini yeterli görmüştür. Neticede "gümüş oxydi" gibi isimler elde etmiştir. Benzer ilaveleri diğer bileşiklere de uygulamış, "esaslar" 1 isimlendirmesinde "hydrat" ve "hydroxyd" ibareleri, "nonmetal oxydleri veya anhydridler" için "anhydridi" ibaresini ismin yanına getirerek kimyasalları Türkçeye uygun hâle getirmeye çalışmıştır.

Artel, asitlerin uluslararası alanda kullanılan şekillerinin Türkçede muhafaza edilmesi fikrindedir. Çünkü asit isimleri kendilerine tekabül eden tuz adlarına "acid" kelimesi ilavesiyle yapılır. Ayrıca, asit isimlerinin tuz adlarından türediğinden bahisle, asitlerin isimlendirilmesi hakkında fazla bir şey söylemeye lüzum olmadığı görüşündedir. Ona göre, sayılarının çokluğu, bazılarının karmaşık yapısından ötürü "tuzlar" için genel kaideler mümkün olmadığı için harfleri münasip şekilde muhafaza edilerek Batı lisanlarındaki tuz isimleri Türkçeye nakledilebilir. Örneğin, iki elementli bir tuz için birinci elementin ismi olduğu gibi söylenirken, ikinci element sonuna "ur" ibaresi getirilir: "altın chloruru".

Artel, “Organik Kimya” bölümüne Avrupa'daki kimya terminolojisi uğraş1s1nın tarihine değinerek başlamıştır. Öyle ki, 1892'deki Cenevre Kongresi ile başlayan kongreler dizisinde 1930'daki Liégé Kongresi'ne değin epeyce yol alınmış, kongrelere organik kimyanın uzmanları katılarak kimya terminolojisine önemli katkılar sağlamışlardır. Artel, "Organik Kimya” bölümünü, "hydrogenli müştaklar", "halogenli ve metalli müştaklar”, "oxygenli müştaklar", "kükürtlü müştaklar", "azotlu müştaklar" ve "heterocyklikler" olarak alt1 başlıkta yapılandırmıştır. Bazı organik kimyasalların isimlendirilmesinde ancak ana hatlara değinebildiğinin altını çizmiştir. Artel bu bölümde organik kimyasalları isimlendirirken sözcüklerin aslına sadık kalmıştır. Uyguladığı yöntem ise bu bölümün alt başliklarında kendini göstermiştir. Mesela günümüz terminolojisinde hidrojen olarak yer alan elementin İngilizce yazılı̧̧ı olan "hydrogen" ibaresine kitabında yer verirken, alkanlar için "alcanlar" demeyi tercih etmiştir. Kökenine bağlı kalmayı "Organik Kimya” bölümü altında yer verdiği tüm kimyasallara uygulamış, "heterocyklikler" başlığında olduğu gibi tüm isimlendirmelerde kökleri korumaya özen göstermiştir. Böylece, organik kimya terimlerinin Türkçeye aktarılmasında köklere dokunmamış, sadece sonlarına ek ilave etmiştir. Neticede bu bölüm, bugünkü kimya terminolojisi bağlamında ne tam manasıla orijinal kimyasal isimlerden ne de Türkçeleşmiş kimyasal isimlerden oluşmuştur. Öyle anlaş1lyyor ki, Artel bu bölüm başında değindiği kongrelerin sonuçlarını benimsediğinden, böyle bir isimlendirmeye gitmiştir.

“Cihaz ve Alet İsimleri” bölümünde Artel, kimya alanında kullanılan cihaz ve aletleri: "Yarı Fennî veya Hiç Fennî Olmayan İsimler Taşıyan Adi Laboratorium Eşyası" ve "Esasları İlmî Kavramlara İstinat Eden ve Tamamen Fennî İsimler Taşıyan Alet ve Cihazlar" olarak ikiye ayırmıştır. Ona göre birinci 
gruptakilerden Türkçeye çevrilebileceklerin bazıları için sorun yoktur. Cihazı ilk kullanan kimyagerlerin, üzerlerinde tadilat yapanların veya fabrikatörlerin isimlerini taşıyan cihazların (örn. "büchner hunisi") isimlendirilmesinde sorun vardır. Şöyle ki, bunlar için öz Türkçe gerekli değildir. Bunlara Türkçe isim konulması hâlinde, hata yapılabileceği görüşünde olan Artel, ikinci gruptaki cihaz ve aletlerin isimlendirmesinde imla meselesinin daha mühim olduğunu düşünmüş, bu nedenle bunların orijinal isimlerinin muhafaza edilmesini desteklemiştir.

\section{Türkşe Kimya Nomenclaturu Nasıl Olmalıdır'a Tepkiler}

Türkşe Kimya Nomenclaturu Nasıl Olmalıdır yayımlandığı dönemde ilgi görmüşür. Mesela Hüseyin Cahit Yalçın 6 Mart 1937 tarihli Fikir Hareketlerindeki yazısında, Artel'in kitabının yeni bir yol açabilecek mahiyette bir yapit olduğuna değinmiştir (1937: 2). Nurullah Ataç ise 13 Mart 1937 tarihli Akşam'da bu kitapla alakalı olarak "Bir Istılah Kitabı" başlıklı bir yazı kaleme almıştır. Yazısında, eksik noktalar ve katılmadığı öneriler olmasına karşın, Artel'in kitabıyla çok değerli bir iş gördüğünü ifade etmiştir (1937: 3). 26 Ocak 1936 tarihli Cumburiyet te yer almış "Türk Kimya Nomenclaturu Nas1l Olmalıdır" başlıklı yazıda ise, Artel'in dil meselesine bakışı tarif edilmiştir. Kitabın sadece lisan değil, son uluslararası kimya kongrelerinde terminoloji mevzuunda alınan resmî karar ve kaideleri de ihtiva ettiği vurgulanmıştır. Yazıda ayrıca, kitabın tüm kimya terminolojisini toplu olarak mütalaa ve tetkik eden ilk Türkçe kitap olduğu belirtilmiştir (1936: 10).

$\mathrm{Bu}$ olumlu tepkilerin yanısıra Artel'in ortaya koyduğu düşüncelerinin bazılarınca kabul görmediği de anlaşılmaktadır. Zira bu hususla alakalı olarak Emre Dölen, Artel'in Arndt ile içine düştüğü fikir ayrılığı neticesinde 1936'da Umumî Kimya Enstitüsü’nden ayrıldığını belirtmiştir (2010: 431). İsimlendirmede açığa çıkan bu farklılık önemlidir. İsmet Gürgey, Arndt'ın Türkçeyi ikinci anadili olarak benimsediğini, onun kitaplarının sonunda kimyasal sözcük ve kavramları Türkçe, Osmanlı Türkçesi, Almanca, İngilizce olarak karşılaştırmalı şekilde veren bir Lügatçe bulunduğunu anlatmıştır. Gürgey ayrıca, Arndt'ın Türkçeyi kullanmada titiz olduğunu, gerektiğinde sözcük türetmekten kaçınmadığını, hatta "çözücü”, “çözelti”, "çözünme”, "tartı", "değerlik”, “anıklamak”, “anıklantı (preparat)”, "seyreltik”, "çökelti” gibi sözcüklerin Arndt'a ait olduğuna inanıldığını yazmıştır (2005: 87-88). Bu bağlamda; Türkçe sözcüklerin kullanımında Arndt, Artel'e nazaran daha esnek bir tavır sergilemiş gibi görünmektedir. Fakat bu çıkarım Artel'in Türkçe kimya sözcüklerine karşı olduğu şeklinde anlaşılmamalıdır. Zira kitabından anlaşıldığına göre, Türkçeye nakledilecek kelimelerin bulunmasında karşıla- 
ş1labilecek güçlüğü göz önüne alarak Artel'in böyle bir düşünceyi kabul ettiği söylenebilir.

Arndt, 1933'ten 1955'e yirmi iki sene Türkiye'de Umumî Kimya Profesörlüğü ve Umumî Kimya Enstitüsü Müdürlüğü yapmıştır (Eraş 1956: 36-38). Kendisinin çok sayıda eseri ${ }^{2}$ bulunup muhtelif çalı̧̧malara da katılmıştır. Bunlardan biri, önceki bölümde değinildiği üzere 1936'da Türk Dil Kurumu tarafindan kurulan Kimya Terimleri Komisyonu'ndaki görevidir.

Akil Muhtar Özden, ilk ve orta öğretimdeki cisim isimlerinin kendi komisyonlarının kabul ettiği terimlerle ekseriyetle aynı olduğunu yazmıştır. Yalnızca organik asitlerin isimlendirmesinin önceden Cenevre'de kabul edilmiş sisteme göre "metanoyik etanoyik asid" şeklinde yapıldığını, bunun mantıklı görünmesine rağmen Arndt'ın bu adların hiçbir yerde bulunmadığını söylediğini anlatmıştır (Özden 1938: 2). Artel ise Cenevre Kongresi'yle başlayıp Liégé Kongresi'yle şekillenen kimya terminolojisine bağlı kalmıştır; nitekim Artel ile Arndt'ın bu husustaki fikirleri farklıdır denilebilir. Neticede, Artel'in kitabının olumlu veya olumsuz tepkiler aldığı söylenebilir. Ancak, kitabında yer alan düşüncelerinin terminoloji hususunda yapılan çalışmalarda pek de dikkate alınmadığı anlaşılmaktadır ki, üniversite hayatı sonrasındaki eserlerinden bu sonuç açığa çıkmaktadır.

Artel'in Türkçe kimya terminolojisi hususundaki meşguliyeti sadece Türkçe Kimya Nomenclaturu Nasıl Olmalıdır ile sinırlanamaz. Zira üniversiteden ayrıldıktan sonra çevirisini yaptığı Kimya, Radioaktivite, Britannicus kitapları ile Kimya Annali, Kimya ve Sanayi mecmualarında terminoloji konusunu ele almıştır. Artel ayrıca Türk Kimya Cemiyeti üyeliğinde de bulunmuştur (Türk Kimya Cemiyeti Nizamnamesi 1943: 3, 14). Cemiyet kimya terminolojisiyle meşgul olmuş, yayımladığı Kimya Annali ve Kimya ve Sanayinin muhtelif sayılarında bu konudaki yazılara yer verilmiştir. Kimya ve Sanayinnin Ağustos 1953 sayısındaki Artel'in "İlmî Termler Hakkında" başlıklı makalesi bunlardan biridir.

\section{"İlmî Termler Hakkında"}

Artel, 1953’e gelindiğinde terminoloji alanında sorun olduğunu düşündüğünden, mevzuya bir kez daha dönmek ihtiyacını duymuş ve "İlmî Termler Hakkında" başlıklı makalesini kaleme almıştır. Yazar, Türkçe kimya terminolojisi için izlenmesini lüzumlu gördüğü yöntemlere ilişkin öneri ve dü-

2 Kısa Kimya Tatbikatı, Denel Anorganik Kimya (Doç. Dr. Lütfi Ergener ile), İlk Tatbikat (Doç. Dr. Lütfi Ergener ile), Yeni Denel Organik Kimya (Doç. Dr. Lütfi Ergener ile), Ord. Prof. Dr. Fritz. Arndt'ın Yașamöyküsü Arndt'in yapitlarıdır. 
şüncelerini o devrin bazı cereyanlarına aykırı bulunmasına rağmen 1935 'teki kitabında çekinmeden ortaya attı̆̆ını vurgulamıştır. Buna göre, ileri sürdüğü isim verme sistemi, bu senelerde bazılarının "büyüklerimiz böyle istiyor" iddiasını öne sürmesiyle kabul görmemiştir. Artel, ufak tefek tadilatlar dışında 1953'e gelindiğinde aynı görüşlerinde ısrarlıdır ve "İlmî Termler Hakkında" bu nedenle yazılmıştır. Artel bu makalede, Fransızca, İngilizce, Almanca lisanlarında yapıldığı gibi terminoloji oluşturulurken ilmî kelimelerin köklerini muhafaza etmek yerine İtalyanca ve İspanyolcadaki yöntemin Türkçe için de uygulanması gerektiğini öne sürer. Zira İtalyanca ve İspanyolcada ilmî kelimeler bu dillere göre uyarlanmış, kökler değişmiştir. Bu iddiaya göre Türkçede de aynı yöntem izlenmeli, kelimeler alınırken kökler değişmelidir. Artel, hiçbir bilimsel gerekçe göstermeksizin ileri sürülen kimi itirazları cevaplandırmak için mevzuyu ana hatlarıyla tekrar açıklamayı yerinde bulmuş, bu makalesinde 1935 'teki kitabında yazdığ görüşlerini yeniden anlatmıştır. Burada, medenî dilleri, lisanda yapılacak sslahat ve değişiklikleri dikkate alarak "umumî dil" ve "ilim dili" olarak ikiye ayırmıştır. "Umumî dil” yaşayan bir organizmadır; bu bölüme yeni kelimeler eklenebilir. Bunu da o lisanla yazan ve konuşan edipler, büyük yazar ve hatipler yapar. Bu uzun yıllar alabilir ve alınan kelime sayısı uzun zamana rağmen az olabilir. Ancak Artel'e göre, bu durum "ilim dili” için farklıdır. Çünkü "ilim dili”nin kendine has vasıfları vardır ve millî dillerin bunları dilediği gibi değiştirmeye hakları yoktur. Bu durumu "ilim dili”nin küçümsenmesiyle ilişkilendiren Artel, aslında böyle olmaması gerektiği görüşündedir.

İlim ve fende ileri toplulukların dilleri tetkik edildiğinde, ilmî terimlerin bariz şekilde dilin kelime kapasitesinin çoğunluğunu teşkil ettiği görülür. Öyle ki, yaklaşı 32.000 kelime bulunan Fransızcadaki kelimelerin 20.000'ini yani \%62,5'ini ilmî kelime ve terimler oluşturur. Artel'e göre, 1928 öncesindeki bir istatistikte 22.000 kelimeyle Fransızcadan sonra gelen Türkçenin sözü edilen oranda ilmî kelime ve terim ihtiva etmesini beklemek doğaldır. Peki, Türkçenin 1953 itibarıyla bu hususta vaziyeti nedir? Maarif Vekilliği'nin 1941'de neşrettiği cep kılavuzunda, 3000 kadar terim, felsefe ve içtimaî ilimlere ilişkinse birkaç yüz terim bulunur. Artel'e göre bunlardan birçoğu da acelece tespit edilmiş, öğretim zümresinin ihtiyaçlarını karşılayamayan, doğru ve uygun olmayan tabirlerdir. Şu halde 3000-3500 ilmî kelimesiyle Türkçe, Fransızcayla mukayese edildiğinde bu boşluğu nasıl dolduracaktır? Artel'e göre, bunun yolu Batı'nın ileri lisanlarında uygulanan yöntemdir. Fakat dikkat edilecek nokta ilmî kelimelerin müşterek dilden ayrı tutulmasıdır. Bu kelimeler, müşterek dilde mevcut olan kelimelere özel, belirli ve kolay anlaşlır manalar atfedilmek suretiyle terim haline gelmiştir. Bunlar, müşterek dilde mevcut olmayıp da ölü ve bazen de yaşayan dillerden alınan kök ve ekler yardımıyla inşa 
edilmiş kelimelerden oluşur. İlmî kelimeler anlamları itibarıyla sistematiktir. Bu sistematik yapının avantajı uluslararası karakter sergilemesidir. Buna karşın, müşterek dildeki kelimeler geçmişten gelen gelenek ve kullanıma bağlı olarak yerleşmiş ve dile girmiştir.

Artel, bu bahse Türkşe Kimya Nomenclaturu Nasıl Olmalıdır'da yer verdiğini vurgulamıştır. Buna göre, çözüme ilmin uluslararası olduğu hakikatinin kabulüyle ulaşılabilir. Öyleyse Türkiye uluslararası terimleri kabul etmelidir. Bundan kasıt uluslararası kelimelerin okunuşu değil yazılışıdır. Bu konuda da yine Batı'nın büyük dilleri olan Fransızca, İngilizce ve Almanca model alınmalıdır. Zira bu dillerde imla konusunda esas olan telaffuz değil, yazılışa dayanarak ilmî kelimelerin tespitidir. Fransızca, İngilizce hatta Almancada kelimeler etimoloji ile kullanım ve geleneğin tespit ettiği telaffuz tarzı olmak üzere iki esas temelinde saptanmıştır. Türkiye'de 1928 'de başlayan dil hareketiyle Türkçe kelimeler söylendiği gibi yazılır kaidesi uygulanmış, sonuçta 1953'e gelindiğinde ilmî kelime açısından 3000-3500 sayısına ancak erişilebilmiştir. Artel’e göre en büyük hata burada yapılmıştır. Ona göre bu yöntem yanlıştır ve bundan vazgeçilmelidir. Bu netice, ilmî terimler gibi akademik bir mevzunun politik veya kişisel ve öznel görüşler temelinde ele alınmasından kaynaklanır. Artel, Türkçe ilmî kelimelerin artırılması konusunda 1953’e gelindiğinde öne çıan en büyük engelin alfabenin eksikliği olduğu görüşündedir. Ona göre, alfabeye q, $\mathrm{x}$ ve hatta w harfleri eklenmeli; y eski alfabedeki gibi hem sedalı hem sedasız harf olarak kullanılmalı; ch veya kh, th ve ph gibi çift harflerden yararlanılmalıdır. Ayrıca, terminoloji mevzuunda Latincenin c harfine dokunulmamalı ve bu harfe bir işaret ilavesiyle dj yani eski cim sedasinı veren millî bir harf ilave edilmeli, hatta a ve 1 harflerinde bazı tadiller yapılmalıdır. Bu yenilikler ilk bakışta zorluk çıkaracak gibi görünse de, binlerce kelimenin Türkçeye nakline olanak sağlayacaktır. Artel, 1935'teki sistemini Türkçe kimya terimlerinin naklinde karşılaşılan sorunları çözmeye yönelik olarak önerdiği ancak önerisinin terminoloji çalışmalarında değerlendirilmediğinden kasitla, bu konuda anlaşılmaz bir ssrar ve ihmal sonucu ülkenin gereksiz yere uzun zaman kaybettiği düşüncesindedir. Ona göre, çözüm bu ısrardan vazgeçilip kendisinin önerdiği sistemin tatbik edilmesidir.

\section{Sonuç}

Türkçe kimya terminolojisi hususunda Türkiye'nin Batı'ya yönelmesini savunduğu anlaşılan Artel, Batı’da kullanılan ve uluslararası nitelik kazanmış sözcüklerin Türkçe terminolojiye alınmasında bunların köklerinin muhafaza edilmesi fikrindedir. Fakat görülüyor ki, arka çıktığı bu yönelim ve önerdiği sistem, çağının Türkiye'de ağırlık kazanan dil politikaları ile paralellik göster- 
memiştir. Bu farklılığa rağmen Artel'in önerdiği sistem yine de tartı̧̧labilir. $\mathrm{Bu}$ düşüncelerden ilerleyen süreçte istifade edilebilirdi ama anlaşıliyor ki bu söz konusu olmamıştır. Buna karşın, farkındalık oluşturma, tartı̧̧ma ortamı yaratma açısından Artel'in Türkçe kimya terminolojisine katkı sağladığını söylemek mümkündür.

Günümüz anlayışı çerçevesinde fikirlerinin yerindeliği tartışılabilir olsa da, şunu akılda tutmak gerekir ki, Artel Türkçenin de Fransızca, İngilizce, Almanca gibi bilimsel terimler zenginliği açısından ileri Batı dilleri gibi olması için gayret göstermiştir. Tüm kimya terminolojisini bir arada işlemiş, alanında ilk olduğu anlaşılan bir kitap kaleme almış, ancak fikirleri kabul görmemiştir. Netice itibariyle, Türkiye bu bilim adamından yeterince istifade edememiştir.

\section{Kaynaklar}

Ataç, Nurullah (26 Ocak 1936). “Türk Kimya Nomenclaturu Nasıl Olmalıdır”, Cumburiyet.

(13 Mart 1937). "Bir Ist1lah Kitabı", Akşam.

Artel, Tarık (1935). Türkşe Kimya Nomenclaturu Nasıl Olmalıdrr, İstanbul: Matbaacıllk ve Neşriyat Türk Anonim Şirketi.

_- (1937). “Türkçe Kimya Nomenclaturu Nasil Olmalıdır”, Kimya ve Sanayi 14, s.II. (1953). “İlmî Termler Hakkında”, Kimya ve Sanayi 28-29, s.397-405.

Dölen, Emre (2010). Türkiye Üniversite Taribi 4: İstanbul Üniversitesi (1933-1946), İstanbul: Bilgi Üniversitesi Yayınları.

Eraş, Ekrem (1956). "Kimyayı ve Kimya Sanayiini Türklere Lâyık Görmeyen Prof. Fritz Arndt Diyor ki”, Kimya ve Sanayi, Nisan, s.36-38.

Ertem, Gözen (1982). “Fen Fakültesinde Kimya Öğretiminin Geçmişi”, İstanbul Üniversitesi Fen Fakültesi'nde Çeşitli Fen Bilimi Dallarının Cumhuriyet Dönemindeki Gelişmesi ve Milletlerarası Bilime Katkısı, İstanbul: İstanbul Üniversitesi Yayınları.

Gürgey, İsmet (2005). "Türkçe Aşı̆̆ı Bir Bilim Adamı Ord. Prof. Dr. Fritz Arndt", Çağdaş Türk Dili 206, s.87-88.

İlk ve Orta Ögretim Kimya Terimleri, Elemanlarn Adları İle Bileşik Cisimlerin Genel Adlanma Yollar (1937). İstanbul: Devlet Basımevi.

İlk ve Orta Öğretim Kimya Terimleri, Türkşe-Osmanlıca, Osmanlica-Türkçe, FransızcaTürkse (1937). İstanbul: Devlet Basımevi.

Kimya Annali, 1937-1939.

Kimya ve Sanayi, 1950-1966.

Kimya Kitapları Düzeltme Kılavuzu (1940). İstanbul: Maarif Matbaası.

Özden, Akil Muhtar (1938). Yeni Kimya Terimlerimiz, Ahmet İhsan Basım Evi.

Terem, Haldun N. (1967). “Acı Kaybımı: Tarık Artel”, Kimya ve Sanayi 67-68, s.74-76.

Türk Kimya Cemiyeti Nizamnamesi (1943). İstanbul: Vakit Matbaası. 


\section{ABSTRACT \\ Tarık Artel and Turkish Chemistry Terminology}

One of the books written on Turkish chemistry terminology is Tarik Artel's Türkse Kimya Nomenclaturu Nasıl Olmalddır which was published in 1935. Artel was regarded as a pioneering scientist who made a considerable contribution to Turkish chemistry terminology. In 1930s, intensive efforts continued to construct the chemistry terminology in Turkish. Artel, whose opinions on terminology were not fully supported, wrote an article entitled "On Scientific Terms" in 1953, taking the situation of cehmistry terminology problem in Turkish into account. In this article, Artel's views are portrayed based on his works mentioned above. In the light of the outputs obtained, Artel's contribution to Turkish chemistry terminology and his share in the progress of Turkish chemistry are presented.

Keywords: Chemistry, Turkish, terminology, Tarık Artel, Türkçe Kimya Nomenclaturu Nasıl Olmalıdır 